\title{
Spider-venom peptides that target voltage-gated sodium channels: pharmacological tools and potential therapeutic leads
}

\author{
Julie K. Klint ${ }^{1}$, Sebastian Senff ${ }^{1}$, Darshani B. Rupasinghe ${ }^{1}$, Sing Yan ${ }^{1}$, \\ Volker Herzig $^{1}$, Graham M. Nicholson ${ }^{2}$, and Glenn F. King ${ }^{1}{ }^{1 *}$ \\ ${ }^{1}$ Institute for Molecular Bioscience, The University of Queensland, \\ 306 Carmody Rd, St. Lucia, QLD 4072, Australia \\ ${ }^{2}$ Neurotoxin Research Group, School of Medical \& Molecular Biosciences, \\ University of Technology, Sydney, Broadway NSW 2007, Australia
}

Address for correspondence: Prof. Glenn F. King, Institute for Molecular Bioscience, The University of Queensland, 306 Carmody Road, St Lucia, QLD 4072, Australia; Phone: +61 7 3346-2025; Fax: +61 7 3346-2021; Email: glenn.king@imb.uq.edu.au 


\begin{abstract}
Voltage-gated sodium $\left(\mathrm{Na}_{\mathrm{V}}\right)$ channels play a central role in the propagation of action potentials in excitable cells in both humans and insects. Many venomous animals have therefore evolved toxins that modulate the activity of $\mathrm{Na}_{\mathrm{V}}$ channels in order to subdue their prey and deter predators. Spider venoms in particular are rich in $\mathrm{Na}_{\mathrm{V}}$ channel modulators, with one third of all known ion channel toxins from spider venoms acting on $\mathrm{Na}_{\mathrm{V}}$ channels. Here we review the landscape of spider-venom peptides that have so far been described to target vertebrate or invertebrate $\mathrm{Na}_{\mathrm{V}}$ channels. These peptides fall into 12 distinct families based on their primary structure and cysteine scaffold. Some of these peptides have become useful pharmacological tools, while others have potential as therapeutic leads because they target specific $\mathrm{Na}_{\mathrm{V}}$ channel subtypes that are considered to be important analgesic targets. Spider venoms are conservatively predicted to contain more than 10 million bioactive peptides and so far only $0.01 \%$ of this diversity been characterised. Thus, it is likely that future research will reveal additional structural classes of spider-venom peptides that target $\mathrm{Na}_{\mathrm{V}}$ channels.
\end{abstract}

Keywords: spider venom; peptide; inhibitor cystine knot; voltage-gated sodium channel; therapeutic; analgesic; insecticide; ArachnoServer; $\mathrm{Na}_{\mathrm{V}} 1.7$ 


\section{Introduction}

More than 42,700 extant species of spiders have been described (Platnick, 1997), with an even greater number remaining to be characterised (Coddington and Levi, 1991), making them the largest group of terrestrial predators. One of the major contributors to the evolutionary success of spiders is their ability to produce complex venoms for predation and predator deterrence (King, 2004). Spider venoms are complex chemical cocktails but the major components are small, disulfide-rich peptides. Since a single venom can contain as many as 1,000 peptides, it has been conservatively estimated that $>10$ million bioactive peptides are likely to be present in the venoms of spiders (Escoubas et al., 2006), with only $0.01 \%$ of this diversity having been characterised. The spider-venom peptides that have been described to date are detailed in ArachnoServer, a manually curated database that provides detailed information about proteinaceous toxins from spiders (Wood et al., 2009; Herzig et al., 2011).

Voltage-gated sodium $\left(\mathrm{Na}_{\mathrm{V}}\right)$ channels play a key role in the rising phase of the action potential in excitable cells (Catterall et al., 2005). In contrast with vertebrates, insects express only a single $\mathrm{Na}_{\mathrm{V}}$ channel subtype (King et al., 2008a) and consequently they are extremely sensitive to $\mathrm{Na}_{\mathrm{V}}$ channel modulators, as underlined by the fact that several of the most successful classes of chemical insecticides are $\mathrm{Na}_{\mathrm{V}}$ channel modulators (e.g., pyrethroids, indoxacarb, dihydropyrazoles, $\mathrm{N}$-alkylamides, and DDT) (Soderlund and Knipple, 1995; Bloomquist et al., 1996; Zlotkin, 1999). One-third of the 186 ion channel modulators listed in ArachnoServer target $\mathrm{Na}_{\mathrm{V}}$ channels (Fig. 1), which is perhaps not surprising as these toxins allow spiders to rapidly incapacitate their prey. $\mathrm{Na}_{\mathrm{V}}$ channel toxins are found in a taxonomically diverse range of spiders, which suggests that this pharmacology was recruited at a very early stage in venom gland evolution. Moreover, the ubiquity of $\mathrm{Na}_{\mathrm{V}}$ channel toxins in spider venoms suggests that these peptides might be useful insecticides for the control of arthropod pests (Maggio et al., 2010; Windley et al., 2012).

In addition to prey capture, spiders also use their venom to deter predators, which can include vertebrates. Moreover, even though the vast majority of spiders prey primarily on invertebrates, there is no evolutionary selection pressure to prevent spider toxins acting on vertebrate ion channels. It is therefore not surprising that many spider-venom peptides have been found to modulate the activity of vertebrate $\mathrm{Na}_{\mathrm{V}}$ channels (Nicholson and Little, 2005; Escoubas and Bosmans, 2007; King et al., 2008a). 


\section{Nav channels}

In both vertebrates and invertebrates, functional $\mathrm{Na}_{\mathrm{V}}$ channels are composed primarily of a large pore-forming $\alpha$ subunit (220-260 kDa) whose gating and kinetics are modified via association with one of four smaller $\beta$ subunits (33-36 kDa) in the case of vertebrates or the unrelated TipE accessory subunit (65 kDa) in the case of invertebrates (King et al., 2008a). The $\alpha$ subunit is composed of four homologous but non-identical domains (designated I-IV) connected by intracellular linkers (Fig. 2). Each of these domains contains six transmembrane (TM) segments (S1-S6) joined by intracellular or extracellular loops. Membrane re-entrant loops between TM segments S5 and S6 dip into the TM region of the protein and form the narrow ion-selectivity filter at the extracellular end of the pore (Fig. 2). During action potential generation, the channel cycles through three states: closed, open, and inactivated. The S4 segments contain a positively charged amino acid (Arg or Lys) at every third position; this segment serves as a 'voltage sensor' that initiates voltage-dependent activation (i.e., the transition from the closed to open state) by responding to membrane depolarization and causing the channel to undergo a conformational change that allows selective influx of $\mathrm{Na}^{+}$ ions through the pore. Sodium channel inactivation (i.e., the transition from the open to inactivated state) is mediated by a short intracellular loop termed the "inactivation gate" that connects domains III and IV (Fig. 2). In a major breakthrough, the three-dimensional structure of a bacterial $\mathrm{Na}_{\mathrm{V}}$ channel in the closed state was recently determined (Payandeh et al., 2011), which should allow molecular modelling of the interaction between $\mathrm{Na}_{\mathrm{V}}$ channels and ligands that modulate their activity.

In vertebrates, the $\alpha$ subunits are classified into nine different subtypes, denoted $\mathrm{Na}_{\mathrm{V}} 1.1$ to $\mathrm{Na}_{\mathrm{V}} 1.9$, and they are further characterised by their sensitivity to tetrodotoxin (TTX). Nav1.5, $\mathrm{Na}_{V} 1.8$ and $\mathrm{Na}_{\mathrm{V}} 1.9$ are TTX-resistant, whereas all other subtypes are TTX-sensitive (Catterall et al., 2005; King et al., 2008a). A combination of site-directed mutagenesis, binding studies, and electrophysiological approaches have been used to identify at least seven distinct ligand binding sites in or around the pore region of the $\mathrm{Na}_{\mathrm{V}}$ channel $\alpha$ subunit, as shown in Fig. 2 . The majority of these sites have been identified using venom molecules and alkaloids as pharmacological probes (King et al., 2008a). Venom peptides modulate channel activity by two main mechanisms: they either physically occlude the channel pore or they bind to an allosteric site that induces a conformational change in the channel that alters the equilibrium between the open, closed, and inactivated states (Ekberg et al., 2008). 
All known $\mathrm{Na}_{\mathrm{V}}$ channel toxins from spider venoms are allosteric modulators, also known as "gating modifiers". However, they modulate channel activity in quite different ways. For example, the lethal toxin from the Sydney funnel-web spider Atrax robustus ( $\delta$-HXTX-Ar1a) inhibits the inactivation of both insect and vertebrate $\mathrm{Na}_{\mathrm{V}}$ channels (Nicholson et al., 1998; Grolleau et al., 2001), whereas the $\mu$-agatoxins from unrelated American funnel spiders shift the voltage for channel activation to more negative potentials, increasing the probability of channel opening at the resting membrane potential (Adams, 2004).

\section{Spider toxins that target $\mathrm{Na}_{\mathrm{v}}$ channels}

The primary aim of this review is to survey the range of peptide sequences and threedimensional scaffolds that have been evolved by spiders for targeting $\mathrm{Na}_{\mathrm{V}}$ channels, with an emphasis on those peptides that might have therapeutic potential. The 'Browse by Molecular Targets' ontology in ArachnoServer (Wood et al., 2009; Herzig et al., 2011) was used to extract all known spider-venom peptides with activity on $\mathrm{Na}_{\mathrm{V}}$ channels (both vertebrate and invertebrate). Homologs of these toxins were found by using the BLAST function within ArachnoServer. CLC sequence viewer 6 (CLC bio, Denmark) was used to align the peptides and generate families of related peptides based on the level of sequence identity and intercysteine spacings. This resulted in 12 different families of spider-venom peptides that target $\mathrm{Na}_{\mathrm{V}}$ channels, as outlined in Figures 3 and 4. The following sections describe the activity data that is currently available for each family. These sections employ the rational nomenclature recently developed for spider-venom peptides (King et al., 2008b) in order to facilitate identification of orthologs and paralogs, but for convenience we also provide original names of toxins. The term NaScTx is employed for scorpion toxins that target $\mathrm{Na}_{\mathrm{V}}$ channels (Rodriguez de la Vega and Possani, 2005), and here we introduce the term NaSpTx for spider toxins that target this channel.

Family 1: All peptides in Family 1 were isolated from the venom of tarantulas (Theraphosidae), and they consist of 33-35 amino acid residues with three disulfide bridges that form an inhibitor cystine knot (ICK) motif, defined as an antiparallel $\beta$ sheet stabilised by a cystine knot (Pallaghy et al., 1994). In spider toxins, the $\beta$ sheet typically comprises only two $\beta$ strands although a third N-terminal strand is sometimes present (King et al., 2002). The cystine knot itself comprises a ring formed by two disulfides and the intervening sections of the peptide backbone, with a third disulfide piercing the ring to create a pseudo-knot (Saez et 
al., 2010). This "knot" converts ICK peptides into hyperstable mini-proteins with tremendous chemical, thermal, and biological stability. ICK toxins are typically resistant to extremes of $\mathrm{pH}$, organic solvents, high temperatures, and proteases (Saez et al., 2010). Of the 10 families of NaSpTxs whose disulfide connectivity has been determined or which can be confidently predicted based on homology (see Figures 3 and 4), nine contain an ICK motif.

One member of Family 1 ( $\mu / \omega$-TRTX-Hh1a; huwentoxin-1) was found to be analgesic in a rat model of formalin-induced pain when administered intrathecally (Chen et al., 2005), although in another study the same peptide was reported to be lethal to mice when delivered via the intraperitoneal or intracisternal route (Liang et al., 1993). Intraperitoneal administration of $\mu$-TRTX-Hhn $1 \mathrm{~b}$ (hainantoxin-IV) is also lethal to mice with an $\mathrm{LD}_{50}$ of $0.2 \mathrm{mg} / \mathrm{kg}$ (Liu et al., 2003), as is intracerebroventricular (i.c.v.) administration of $\beta$-TRTX-Ps1a (phrixotoxin-3), $\beta$-TRTX-Cm1a (ceratotoxin-1), and $\beta$-TRTX-Cm1b (ceratotoxin-1) (Bosmans et al., 2006).

Despite the high level of residue conservation throughout this family, the selectivity of the peptides for the various $\mathrm{Na}_{\mathrm{V}}$ channel subtypes varies dramatically. For example, $\beta$-TRTXPsla potently blocks $\mathrm{Na}_{\mathrm{V}} 1.5$ with an $\mathrm{IC}_{50}$ of $72 \mathrm{nM}$ (Bosmans et al., 2006) whereas $\mu$-TRTXHh2a (huwentoxin-4), which is $62 \%$ identical to $\beta$-TRTX-Ps1a, does not have any effect on $\mathrm{Na}_{\mathrm{V}} 1.5$ at concentrations up to $10 \mu \mathrm{M}$ (Xiao et al., 2008). Based on homology with other toxins, peptides in Family 1 are presumed to function as gating modifiers (Bosmans et al., 2006). Consistent with this hypothesis, analysis of the binding of $\mu$-TRTX-Hh2a to mutants of $\mathrm{Na}_{\mathrm{V}} 1.4$ revealed that the peptide interacts with the S3-S4 linker of channel domain II (i.e., neurotoxin receptor site 4; see Fig. 2), with the blocking effect achieved by trapping the domain II voltage sensor in the closed configuration (Xiao et al., 2008). In contrast, $\mu$-TRTXHhn $1 \mathrm{~b}$ was shown to have no effect on the activation or inactivation kinetics of TTX-S Na currents in rat dorsal root ganglion (DRG) neurons and therefore it was hypothesised to function not as a gating modifier but as a pore blocker by binding at neurotoxin receptor site 1 (Li et al., 2004). However, this would be a very unusual pharmacology for NaSpTxs and it remains to be confirmed by site-directed mutagenesis and competitive binding studies. The functionally important residues on $\mu$-TRTX-Hhn $1 \mathrm{~b}$ have been proposed to be K27 (which is conserved in most Family 1 peptides) and R29 (which is poorly conserved) as mutations of these residues to alanine showed reduced activity (Li et al., 2004). 
Very little work has been done to examine the activity of Family 1 peptides against insect $\mathrm{Na}_{\mathrm{V}}$ channels, but the limited data available indicates that the insecticidal activity of these peptides is likely to be highly variable. $\mu$-TRTX-Hhnlb has no effect when injected into cockroaches (Liu et al., 2003), whereas $\mu / \omega$-TRTX-Hhla potently inhibits $\mathrm{Na}_{\mathrm{V}}$ currents in cockroach dorsal unpaired median (DUM) neurons $\left(\mathrm{IC}_{50}=4.8 \mathrm{nM}\right.$ ) (Wang et al., 2011). Falling between these two extremes is $\mu$-TRTX-Hhn2b (hainantoxin-I), which only weakly inhibits insect $\mathrm{Na}_{\mathrm{V}}$ channels heterologously expressed in Xenopus oocytes $\left(\mathrm{IC}_{50}=4.3 \mu \mathrm{M}\right)(\mathrm{Li}$ et al., 2003).

Family 2: Family 2 is the largest family of NaSpTxs with 34 members, all originating from theraphosid venoms. Of these, 18 peptides were isolated from the Chinese tarantula Chilobrachys jingzhao. Family 2 peptides range in size from 33-41 residues and they each contain three disulfide bonds that form an ICK motif. Currently, there is experimental proof of $\mathrm{Na}_{\mathrm{V}}$ channel activity for only four of the 34 peptides in this family. However, they are very interesting from a therapeutic perspective as one member of this family, $\beta / \omega$-TRTX-Tp1a (protoxin I), is one of the most potent blockers of human $\mathrm{Na}_{\mathrm{V}} 1.7$ reported to date, with an $\mathrm{IC}_{50}$ of $51 \mathrm{nM}$ (Middleton et al., 2002; Priest et al., 2007).

K-TRTX-Cj1a (Jingzhaotoxin-11) is a weak modulator of $\mathrm{Na}_{\mathrm{V}}$ currents in cardiac myocytes (i.e., mainly TTX-R $\mathrm{Na}_{\mathrm{V}} 1.5$ ), causing a significant reduction in peak $\mathrm{Na}_{\mathrm{V}}$ current amplitude and a slowing of $\mathrm{Na}_{\mathrm{V}}$ current inactivation $\left(\mathrm{IC}_{50}=1280 \mathrm{nM}\right)$ (Liao et al., 2006). It also inhibits $\mathrm{K}_{\mathrm{V}} 2.1$ with moderate potency $\left(\mathrm{IC}_{50}=740 \mathrm{nM}\right)$, with even weaker block of $\mathrm{K}_{\mathrm{V}} 4.1$ and $\mathrm{K}_{\mathrm{V}} 4.2$ and no effect on $\mathrm{K}_{\mathrm{V}} 1.1, \mathrm{~K}_{\mathrm{V}} 1.2, \mathrm{~K}_{\mathrm{V}} 1.3, \mathrm{~K}_{\mathrm{V}} 1.4$ and $\mathrm{K}_{\mathrm{V}} 3.1$ (Liao et al., 2006). A peptide with identical sequence has been isolated from the venom of the related theraphosid spider Plesiophrictus guangxiensis. It has been proposed that $\kappa$-TRTX-Cj1a binds to the extracellular S3-S4 linker region of channel domain IV (i.e., neurotoxin receptor site 3; see Fig. 2) (Liao et al., 2006), which is a common target of gating modifier toxins such as א-TRTX-Grla (Hanatoxin-1) in the same family (Li-Smerin and Swartz, 1998).

$\beta$-TRTX-Cm2a (Ceratotoxin-3) has moderate affinity towards $\mathrm{Na}_{\mathrm{V}} 1.5\left(\mathrm{IC}_{50}=447 \mathrm{nM}\right)$, and at a concentration of $2 \mu \mathrm{M}$ it weakly blocks $\mathrm{Na}_{\mathrm{V}} 1.8$ (45\% reduction in current) but has no activity against $\mathrm{Na}_{\mathrm{V}} 1.1-1.4$ (Bosmans et al., 2006). In striking contrast with $\kappa-T R T X-C j 1 \mathrm{a}$ and $\beta$-TRTX-Cm2a, $\mu$-TRTX-Cj1a (Jingzhaotoxin-34) is a potent blocker of TTX-S Na channels in rat dorsal root ganglion $(\mathrm{DRG})$ neurons $\left(\mathrm{IC}_{50}=85 \mathrm{nM}\right)$ but it has no effect on 
TTX-R Na $\mathrm{V}_{\mathrm{V}}$ currents (Chen et al., 2009). Thus, residues that are conserved in $\kappa-T R T X-C j 1 \mathrm{a}$ and $\beta$-TRTX-Cm2a, but which are absent from $\mu$-TRTX-Cj1a, should provide some insight into residues that are important for interaction of this family of peptides with $\mathrm{Na}_{\vee} 1.5$.

Six toxins from Family 2 have confirmed activity on voltage-gated calcium $\left(\mathrm{Ca}_{\mathrm{V}}\right)$ channels, with 12 toxins active against $\mathrm{K}_{\mathrm{V}}$ channels. Nevertheless, the high level of sequence identity within this family and the potency of the known Family $2 \mathrm{Na}_{\mathrm{V}}$ modulators described above indicates that a thorough functional analysis of all toxins in this family could reveal many more toxins acting on $\mathrm{Na}_{\mathrm{V}}$ channels. However, from a therapeutic perspective, the promiscuous activity of several family members on multiple types of voltage-gated channels indicates that it will be critical to carefully determine the selectivity of any Family 2 peptides that are being considered as therapeutic leads (Chen et al., 2008).

Family 3: This family consists of 14 reported toxins with highly conserved sequences in the C-terminal region. $\kappa$-TRTX-Ps1b (Phrixotoxin-2) and $\kappa-T R T X-G r 2 a(G s M T x-2)$ are identical peptides identified from different genera of tarantulas (Diochot et al., 1999; Oswald et al., 2002); for simplicity, only к-TRTX-Ps1b is given in the alignment (Fig. 3). Family 3 peptides are 29-32 residues long, with three disulfide bonds forming an ICK motif. These peptides act as gating modifiers by binding to the voltage-sensor region (S3-S4 linker) of channel domain II (i.e., neurotoxin receptor site 4; see Fig. 2), thus impeding channel activation and causing the channels to remain in an inactivated state (Sokolov et al., 2007). $\beta / \omega-T R T X-T p 2 a$ (protoxin II) and $\beta$-TRTX-Gr1b (GsAF I) are both selective against the Na 1.7 subtype, an important analgesic target, but their potency differs by $>100$-fold despite $\sim 90 \%$ sequence identity (Priest et al., 2007; Redaelli et al., 2010). $\beta / \omega$-TRTX-Tp2a is the most potent blocker of human $\mathrm{Na}_{\mathrm{V}} 1.7$ reported to date, with an $\mathrm{IC}_{50}$ of $0.3 \mathrm{nM}$ (Schmalhofer et al., 2008). It also inhibits activation of human $\mathrm{Ca}_{\mathrm{V}} 3.1$ currents but at much higher doses $\left(\mathrm{IC}_{50} \sim 1 \mu \mathrm{M}\right)$ (Edgerton et al., 2010). $\beta / \omega$-TRTX-Tp2a is lethal to rats when administered intravenously at doses $\geq 1.0 \mathrm{mg} / \mathrm{kg}$ or intrathecally at doses $\geq 0.1 \mathrm{mg} / \mathrm{kg}$ (Schmalhofer et al., 2008). This is perhaps not surprising as even though $\beta / \omega$-TRTX-Tp2a preferentially blocks $\mathrm{Na}_{\mathrm{V}} 1.7$, it also potently inhibits key peripheral $\mathrm{Na}_{\mathrm{V}}$ channel subtypes (e.g., $\mathrm{Na}_{\mathrm{V}} 1.5, \mathrm{IC}_{50}=79 \mathrm{nM}$ ) as well as central $\mathrm{Na}_{\mathrm{V}}$ channel subtypes (e.g., $\left.\mathrm{Na}_{\mathrm{V}} 1.2, \mathrm{IC}_{50}=41 \mathrm{nM}\right)($ Schmalhofer et al., 2008).

$\beta$-TRTX-Gr1a (GrTx1) is $96 \%$ identical to $\beta$-TRTX-Gr1b, with the only difference being a 
Gln at position 22 instead of Arg. However, this single amino acid change causes a vast difference in selectivity. $\beta$-TRTX-Gr1a has similar potency towards $\mathrm{Na}_{\mathrm{V}} 1.1, \mathrm{Na}_{\mathrm{V}} 1.2, \mathrm{Na}_{\mathrm{V}} 1.3$, $\mathrm{Na}_{\mathrm{V}} 1.6$, and $\mathrm{Na}_{\mathrm{V}} 1.7\left(\mathrm{IC}_{50}\right.$ range of $230-770 \mathrm{nM}$ ) whereas $\beta$-TRTX-Gr1b is $>5$-fold more selective towards $\mathrm{Na}_{\mathrm{V}} 1.7$ (Redaelli et al., 2010). Significant variations in $\mathrm{Na}_{\mathrm{V}}$ channel subtype selectivity due to small sequence variations has been noted previously in scorpion-venom peptides (Weinberger et al., 2010).

Family 4: Of the seven peptides in this family, six were isolated from the venom of Australian funnel-web spiders (family Hexathelidae), whereas the seventh is found in nonrelated Australian mouse spiders (family Actinopodidae). These peptides comprise 42-44 residues with four disulfide bonds, three of them arranged in an ICK motif. They are characterised by an unusual sequence of three consecutive Cys residues in the centre of the primary structure and a disulfide bond that connects the $\mathrm{N}$ - and C-terminal Cys residues. All peptides in this family are lethal to vertebrates, including $\delta$-HXTX-Arla (robustoxin) from the Sydney funnel-web spider Atrax robustus, which was responsible for at least 14 human fatalities prior to the introduction of an effective antivenom in 1980 (Fletcher et al., 1997). Family 4 peptides bind to neurotoxin receptor site 3 (see Fig. 2) and slow inactivation of both vertebrate TTX-sensitive $\mathrm{Na}_{\mathrm{V}}$ channels and insect para-type $\mathrm{Na}_{\mathrm{V}}$ channels (Gunning et al., 2003; Nicholson et al., 2004). Symptoms in primates include immediate disturbances in respiration, blood pressure and heart rate, followed by severe hypotension and death due to respiratory and circulatory failure within a few hours (Mylecharane et al., 1989). With the exception of $\delta$-HXTX-Hv1b (Szeto et al., 2000), all Family 4 peptides exhibit insecticidal activity, causing paralysis and/or lethality in orthopterans, lepidopterans and dipterans (Little et al., 1998; Grolleau et al., 2001).

The activity of $\delta$-HXTX-Mgla (Magi-4), the only member of this family not isolated from an Australian funnel-web spider, was recently tested against the full range of rodent $\mathrm{Na}_{\mathrm{V}}$ subtypes expressed in oocytes (Yamaji et al., 2009). $\delta$-HXTX-Mgla was found to be a potent blocker of the Drosophila para/TipE $\mathrm{Na}_{\mathrm{V}}$ channel $\left(\mathrm{IC}_{50} \sim 23 \mathrm{nM}\right)$, and it potently slowed $\mathrm{Na}_{\mathrm{V}}$ channel inactivation in cockroach DUM neurons ( $\mathrm{EC}_{50} \sim 820 \mathrm{pM}$ ) (Yamaji et al., 2009). Activity on vertebrate $\mathrm{Na}_{\mathrm{V}}$ subtypes was much more modest, perhaps explaining why envenomation by Macrothele gigas does not appear to be a serious medical problem. At a concentration of $5 \mu \mathrm{M}, \delta$-HXTX-Mgla had a significant effect on inactivation of rat $\mathrm{Na}_{\mathrm{V}} 1.1$ 
and mouse $\mathrm{Na}_{\vee} 1.6$, modest effects on rat $\mathrm{Na}_{\vee} 1.2, \mathrm{Na}_{\vee} 1.3$ and $\mathrm{Na}_{\vee} 1.7$, and no effect on rat $\mathrm{Na}_{\mathrm{V}} 1.4$, rat $\mathrm{Na}_{\mathrm{V}} 1.5$ and human $\mathrm{Na}_{\mathrm{V}} 1.8$. In contrast with $\delta$-HXTX-Mg1a, Family 4 toxins from lethal Australian funnel-web spiders, such as $\delta$-HXTX-Hvla, are more potent on vertebrate TTX-sensitive $\mathrm{Na}_{V}$ channels than insect $\mathrm{Na}_{V}$ channels (Nicholson et al., 1996).

Family 5: This family of NaSpTxs comprises only two peptides isolated from closely related hexathelid spiders, both of the genus Macrothele. These peptides contain 28-29 residues with three disulfide bonds forming an ICK motif. $\beta$-HXTX-Mg1a (Magi-5) and $\beta$-HXTX-Mr1a (raventoxin III), from different species of Macrothele, have identical sequences (Zeng et al., 2003) so only $\beta$-HXTX-Mgla is presented in the alignment. These peptides are lethal to rodents, but their insecticidal activity is variable. Intra-thoracic injection of $\mathrm{U}_{12}-\mathrm{HXTX}-\mathrm{Mg} 1 \mathrm{a}$ (Magi-11) in crickets (Gryllus bimaculatus) induced slow-onset paralysis leading to death, while intracranial injection in mice resulted in lacrimation, sweating, and urination followed by paralysis of breathing and death 15 min post-injection. $\beta$-HXTX-Mg1a/ $\beta$-HXTX-Mrla caused reversible paralysis when injected into caterpillars (Spodoptera litura) and had no effect when injected into cockroaches (Periplaneta americana), whereas intraperitoneal injection in mice resulted in excitation, gasping, spastic paralysis, and exophthalmos (bulging of the eyes) followed by death (Satake et al., 2004). $\beta$-HXTX-Mg1a binds to site 4 on vertebrate $\mathrm{Na}_{\mathrm{V}}$ channels (see Fig. 2) and shifts steady-state activation to more hyperpolarised voltages, whereas it has been reported to bind to site 3 on insect channels (Corzo et al., 2003; Zeng et al., 2003; Corzo et al., 2007)

Family 6: All peptides in this family were isolated from the venom of spiders in the family Ctenidae. Four were isolated from the highly venomous Brazilian armed spider Phoneutria nigriventer, one was isolated from the venom of the closely related P. reidyi, and one was identified from a venom gland transcriptome of P. keyserlingi. The final member of the family was isolated from the venom of a related ctenid, the South American fishing spider (Ancylometes sp.). These toxins comprise 47-54 residues and contain five disulfide bonds whose connectivity has not been experimentally determined. Of those that have been tested in vertebrates, all display lethality even at doses as low as $7.5 \mathrm{pmol} / \mathrm{g}$ (Cordeiro et al., 1992). $\delta$-CNTX-Pn2a (Tx2-6) has a complex pharmacology that results in inhibition of $\mathrm{Na}_{\mathrm{V}}$ channel inactivation and a hyperpolarizing shift in the potential required for channel activation (Matavel et al., 2002). Due to the high sequence identity (80-89\%) between members of this 
family, they are all assumed to modulate $\mathrm{Na}_{\mathrm{V}}$ channels in this manner. An interesting supplementary pharmacology has been observed for $\delta$-CNTX-Pn2a, which originated from the observation that males bitten by this spider experience a diverse variety of symptoms including priapism. Although i.c.v. injection of $\delta$-CNTX-Pn2a into rats is lethal, rats with depressed erectile function can be normalised by subcutaneous administration of $\delta$-CNTXPn2a (Nunes et al., 2008). A minimum dose of only $0.006 \mu \mathrm{g} / \mathrm{kg}$ was required to cause an erection in mice when injected directly into the corpus cavernosum and, at this dose, no local and systemic toxic effects were observed (Andrade et al., 2008). Thus, $\delta$-CNTX-Pn2a has been touted as a lead molecule for the development of new therapeutics for treatment of erectile dysfunction that might have fewer side effects than current drugs.

Only limited information is available regarding the insecticidal activity of members of this family. $\delta$-CNTX-Pn2a and $-\operatorname{Pn} 2 \mathrm{~b}(\mathrm{Tx} 2-5)$ were reported to be insecticidal to both the larval and adult forms of the house fly Musca domestica (Cordeiro et al., 1992), however, no $\mathrm{LD}_{50}$ values have been reported.

Family 7: All peptides in this family were isolated from the venom of theraphosid spiders. They each contain 33-36 residues with three disulfide bonds that form an ICK motif.

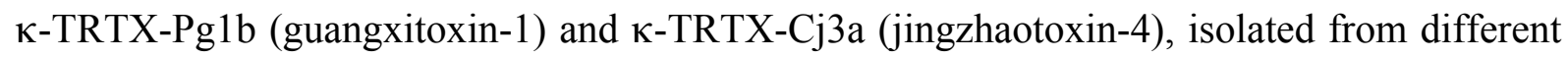
genera, are identical (Herrington et al., 2006; Chen et al., 2008), so only the sequence of $\kappa$-TRTX-Pg1b is presented in the alignment. These peptides appear to have promiscuous activity on both $\mathrm{K}_{\mathrm{V}}$ and $\mathrm{Na}_{\mathrm{V}}$ channels. Although several family members were isolated as $\mathrm{K}_{\mathrm{V}}$ channel blockers, these peptides have not been tested on $\mathrm{Na}_{\mathrm{V}}$ channels. The only two family members that have been directly tested on $\mathrm{Na}_{\mathrm{V}}$ channels displayed significant activity. Both $\beta / \kappa-T R T X-C j 1 \mathrm{a}$ (jingzhaotoxin-3) and $\delta$-TRTX-Cj1a (jingzhaotoxin-1) inhibit activation of $\mathrm{Na}_{\mathrm{V}} 1.5$ with an $\mathrm{IC}_{50}$ of $350 \mathrm{nM}$ and $32 \mathrm{nM}$, respectively (Xiao et al., 2005; Rong et al., 2011), It was recently shown via mutational studies that $\beta / \kappa-T R T X-C j 1$ a binds to the S3-S4 loop of domain II (i.e., neurotoxin receptor site 4; see Fig. 2) in Nav1.5 (Rong et al., 2011).

Little is known about the insecticidal activity of these toxins. Intra-abdominal injection of $\mu$-TRTX-Hh1a (Huwentoxin-3) into cockroaches induces reversible paralysis that lasts for several hours. The effects of other family members on insects or heterologously expressed insect $\mathrm{Na}_{\mathrm{V}}$ channels have not been examined. 
Family 8: This is a small family comprising only three peptides derived from two species of ctenid spiders. These peptides are easily the longest NaSpTxs, with 76-77 residues and seven disulfide bonds. They are similar in size to scorpion $\alpha$ and $\beta$ toxins that also target $\mathrm{Na}_{\mathrm{V}}$ channels (Rodriguez de la Vega and Possani, 2005), but they have no sequence homology and contain a larger number of disulfide bonds. These toxins are lethal to rodents. $\mu$-CNTX-Pn1a (Tx1; PhTx1) from P. nigriventer has an $\mathrm{LD}_{50}$ of $5.5 \mathrm{pmol} / \mathrm{g}$ in mice (Diniz et al., 1990; Diniz et al., 2006), while $\mathrm{U}_{5}-\mathrm{CNTX}-\mathrm{Pk} 1 \mathrm{~b}$ (PKTx1B) caused excitation and spastic paralysis in mice upon i.c.v. administration at a dose of $1.5 \mu \mathrm{g} / \mathrm{mouse}$, followed by death within 5-8 min (Richardson et al., 2006).

Preliminary studies suggested that $\mu$-CNTX-Pn1a might target vertebrate $\mathrm{Ca}_{\mathrm{V}}$ channels (Gouvea dos Santos et al., 1999; Gouvea dos Santos et al., 2002) but more recent studies have shown that it is a state-dependent blocker of rat $\mathrm{Na}_{\mathrm{V}} 1.2$ that binds in the vicinity of channel site 1 (Martin-Moutot et al., 2006). The high level of sequence identity suggests that all members of this family will have the same pharmacology.

Family 9: This family consists of only two paralogous peptides isolated from the venom of the crab spider Heriaeus melloteei. They comprise 37 and 40 residues, with three disulfide bonds that are predicted to form an ICK motif. $\mu$-TMTX-Hmela (Hm-1) has similar potency against $\mathrm{Na}_{\mathrm{V}} 1.2, \mathrm{Na}_{\mathrm{V}} 1.4, \mathrm{Na}_{\mathrm{V}} 1.5$, and $\mathrm{Na}_{\mathrm{V}} 1.6$. $\left(\mathrm{IC}_{50}\right.$ 150-500 nM) but no effect against $\mathrm{Na}_{\mathrm{V}} 1.8$ (Billen et al., 2008). $\mu$-TMTX-Hmelb (Hm-2) has similar pharmacology, except that it has very little activity against $\mathrm{Na}_{\vee} 1.5$ (Billen et al., 2008). The insecticidal activity of these toxins has not been examined.

Family 10: This family comprises venom peptides from the closely related spider families Amaurobiidae and Agelenidae. All members of Family 10 are 36-38 residues long and contain four disulfide bonds, three of which form an ICK motif. With the exception of $\delta$-AMATX-P11a ( $\delta$-palutoxin IT1), all members of Family 10 are C-terminally amidated. The $\mu$-agatoxins ( $\mu$-AGTXs) in Family 10 shift the voltage-activation curve to more negative potentials, increasing the probability of $\mathrm{Na}_{\mathrm{V}}$ channel opening at the resting membrane potential. The resultant membrane depolarization leads to calcium entry into nerve terminals and spontaneous release of neurotransmitter into the neuromuscular junction, as well as 
repetitive action potentials in motor neurons (Skinner et al., 1989; Adams, 2004). The $\delta$-amaurobitoxins, previously known as $\delta$-palutoxins (Corzo et al., 2000), have a quite different mode of action to the $\mu$-agatoxins. They bind to site 4 on insect $\mathrm{Na}_{\mathrm{V}}$ channels (Ferrat et al., 2005) and inhibit channel inactivation, but they have no effect on rat $\mathrm{Na}_{\mathrm{V}} 1.2$ channels at concentrations up to $10 \mu \mathrm{M}$ (Ferrat et al., 2005). They are the only spider toxins that have been definitively shown to bind to site 4 on insect $\mathrm{Na}_{\mathrm{V}}$ channels but which modulate $\mathrm{Na}_{\mathrm{V}}$ channel inactivation (King et al., 2008a)(Windley et al., 2012).

The only toxic effect in vertebrates reported for any member of Family 10 was a temporary paralysis (lasting not longer than $15 \mathrm{~min}$ ) of the left legs of a mouse that received an i.c.v. injection of 486 pmol of $\delta$-AMATX-P11b ( $\delta$-palutoxin IT2) (Corzo et al., 2000). However, a wide range of insecticidal activities have been reported for Family 10 peptides. The $\delta$-amaurobitoxins are weakly insecticidal, with $\mathrm{LD}_{50}$ values of $2347-11029 \mathrm{pmol} / \mathrm{g}$ when injected into larvae of the moth Spodoptera litura (Corzo et al., 2000). The $\mu$-AGTXs from Agelenopsis aperta induced irreversible spastic paralysis when injected into range of insects, with $\mu$-AGTX-Aa1d ( $\mu$-agatoxin IV) being particularly potent in the housefly Musca domestica with an $\mathrm{LD}_{50}$ of $30 \mathrm{pmol} / \mathrm{g}$ (Skinner et al., 1989). The $\mu$-AGTXs from Hololena curta caused rapid irreversible flaccid paralysis when injected into house crickets (Acheta domestica) (Stapleton et al., 1990).

Family 11: Family 11 comprises a group of three paralogous insecticidal peptides isolated from the primitive weaving spider Diguetia canities. These toxins are 56-59 residues long with four disulfide bonds whose configuration has not been experimentally determined. The most potent of the three peptides, $\mu$-diguetoxin-Dc1a (DTX9.2), causes rapid paralysis of lepidopteran larvae with a $\mathrm{PD}_{50}$ of $380 \mathrm{pmol} / \mathrm{g}$, but it is not toxic to mice at doses up to $657 \mathrm{pmol} / \mathrm{g}$ (Krapcho et al., 1995). Neurophysiological experiments indicate that these toxins are highly specific insect $\mathrm{Na}_{\mathrm{V}}$ channel activators that induce hyperexcitability in sensory insect nerves and repetitive firing in skeletal muscles (Bloomquist et al., 1996). The fact that the peptides are not toxic to mice suggests that they are unlikely to have potent effects on vertebrate $\mathrm{Na}_{\mathrm{V}}$ channels.

Family 12: This family consists of three paralogous insecticidal peptides isolated from the hexathelid spider Macrothele gigas. They comprise 38-40 residues with three disulfide bonds 
that are predicted to form an ICK motif. These peptides bind specifically to site 3 on insect $\mathrm{Na}_{V}$ channels, but they have no effect on $\mathrm{Na}_{V}$ channels from rat brain synaptosomes and are not toxic to mice when injected i.c.v. at a dose of $20 \mathrm{pmol} / \mathrm{g}$ (Corzo et al., 2003).

\section{Discussion}

\section{Recruitment of $\mathrm{Na}_{\mathrm{v}}$ toxins into spider venoms}

Spiders appear to have evolved a significantly larger repertoire of $\mathrm{Na}_{\mathrm{V}}$ channel toxins than any other venomous animal. Since insects only express a single $\mathrm{Na}_{\mathrm{V}}$ channel subtype that plays a crucial role in action potential generation (King et al., 2008a), this channel is an excellent target for insect predators wishing to rapidly incapacitate their prey. Thus, it is not surprising that spiders seem to have recruited $\mathrm{Na}_{\mathrm{V}}$ channel toxins into their venoms at a very early stage of venom evolution.

With only a few exceptions, the members within each of the 12 different classes of $\mathrm{Na}_{\mathrm{V}}$ channel toxins outlined in this review were restricted to certain taxonomic families. For example, all peptides in Families 1 and 2 were isolated from spiders of the family Theraphosidae, whereas all peptides in Family 6 originated from spiders in the Ctenidae family. The only exceptions are Family 10, with toxins from the closely related spider families Amaurobiidae and Agelenidae, and Family 4, with toxins from the spider families Hexathelidae and Actinopodidae, which are not closely related but which belong both to the suborder Mygalomorphae. This correlation between $\mathrm{Na}_{\mathrm{V}}$ channel toxin classes and spider families can be easily visualised (see Figures 3-4) using the rational nomenclature developed for spider-venom peptides (King et al., 2008b), which makes it easy to identify orthologous and paralogous relationships. While the close relationship between toxin classes and spider families superficially suggests that spiders recruited particular $\mathrm{Na}_{\mathrm{V}}$ toxin scaffolds at specific stages during the course of spider evolution, it seems more likely that most of these scaffolds are ancient recruitments and that deep phylogenetic relationships are currently obscured by the relatively poor taxonomic sampling of spider venoms. There are currently $\sim 42,700$ characterised species of spiders, yet venom peptides have been isolated from less than 100 .

\section{Comparison with $\mathrm{Nav}$ channel toxins from other venomous animals}

Only two related families of scorpion-venom peptides have been described that target $\mathrm{Na}_{\mathrm{V}}$ channels; they have been separated based on their pharmacological properties and are denoted 
the $\alpha$ and $\beta$ families (Gordon et al., 2007). These so-called long-chain toxins comprise 58-76 residues and they are typically stabilised by four disulfide bonds with a $1-8,2-5,3-6,4-7$ connectivity (Rodriguez de la Vega and Possani, 2005). These toxins have a $\beta \alpha \beta \beta$ topology that is unrelated to any known spider-toxin scaffolds. Like Family $4 \mathrm{NaSpTxs,} \mathrm{scorpion} \alpha$ toxins interact with $\mathrm{Na}_{\mathrm{V}}$ channel site 3 and delay channel inactivation, whereas scorpion $\beta$ toxins bind to site 4 of the channel and shift the threshold for channel activation to more negative potentials.

Three classes of $\mathrm{Na}_{\mathrm{V}}$ channel toxins (Types I-III) have been isolated from sea anemones. They all have a similar pharmacological profile to scorpion $\alpha$ toxins and Family 4 NaSpTxs in that they delay channel inactivation by binding to site 3 (Bosmans and Tytgat, 2007). However, they have a distinct structural scaffold compared to both NaScTxs and NaSpTxs (Norton, 1991). Type 1 and Type II toxins typically comprise 46-49 residues with six cysteine residues arranged into three disulfide bridges, whereas Type III toxins are much shorter, typically comprising 27-32 residues, but also with three disulfide bonds (Norton, 1991; Honma and Shiomi, 2006; Bosmans and Tytgat, 2007; Moran et al., 2009). In none of the three classes of sea anemone $\mathrm{Na}_{\mathrm{v}}$ toxins do the three disulfide bonds form an ICK motif, and none of the 3D scaffolds resemble those of NaScTxs or NaSpTxs.

Three major classes of $\mathrm{Na}_{\mathrm{V}}$ channel toxins have been isolated from the venoms of marine cone snails: the $\mu-, \delta$-, and $\mu \mathrm{O}$-conotoxins. The $\mu$-conotoxins isolated from fish-hunting cone snails are small peptides ( $\sim 20$ residues) with three disulfide bonds that are often selective for the skeletal muscle Nav1.4 subtype (Ekberg et al., 2008; Wilson et al., 2011). They do not structurally resemble $\mathrm{Na}_{\mathrm{V}}$ channel toxins from spiders, scorpions or sea anemones. Moreover, in striking contrast with these latter toxins, the $\mu$-conotoxins are pore blockers rather than gating modifiers that compete with TTX and saxitoxin for binding to neurotoxin receptor site 1 (see Fig. 2) (Ekberg et al., 2008).

Despite their vastly different primary structures and dissimilar modes of action, the $\delta$ - and $\mu \mathrm{O}$-conotoxins are evolutionary related members of the O-superfamily with similar 3D scaffolds (Heinemann and Leipold, 2007). They comprise 29-31 residues with three conserved disulfide bonds that form an ICK motif. Hence, they are structural related to those families of NaSpTxs that also contain an ICK motif. The $\delta$-conotoxins delay channel 
inactivation, resulting in prolongation of action potentials, and hence they functionally resemble scorpion $\alpha$ toxins and Family 4 NaSpTxs. However, unlike these arachnid toxins that bind to channel site 3 , the $\delta$-conotoxins are the defining pharmacology for neurotoxin receptor site 6 on vertebrate $\mathrm{Na}_{\mathrm{V}}$ channels (see Fig. 2). In contrast to the $\delta$-conotoxins, $\mu \mathrm{O}$-conotoxins compete with $\beta$ scorpion toxins for binding to neurotoxin receptor site 4 and they appear to block sodium flow by hindering activation of the voltage sensor in channel domain II, thereby preventing channel opening (Leipold et al., 2007).

In summary, while several classes of NaSpTxs functionally resemble $\mathrm{Na}_{\mathrm{V}}$ channel toxins from other venomous animals, their only structural relatives are the $\delta$ - and $\mu \mathrm{O}$-contoxins from the venom of marine cone snails. It is remarkable that two such taxonomically diverse animals, one confined to marine environments and the other a terrestrial predator, have evolved such similar molecular scaffolds for targeting the $\mathrm{Na}_{\mathrm{V}}$ channels of their prey.

\section{NaSpTxs as insecticides and pharmacological tools}

The 12 classes of NaSpTxs described here present a range of different pharmacologies with respect to their binding site on $\mathrm{Na}_{\mathrm{V}}$ channels and their modulation of channel function. For example, some toxin classes delay channel inactivation (e.g., Family 4) while others alter the voltage-dependence of channel activation (e.g., Family 10). Consequently many NaSpTxs have become valuable tools for probing the pharmacology and biophysics of $\mathrm{Na}_{\mathrm{V}}$ channels (Bosmans and Swartz, 2010).

Some NaSpTxs are also promising leads for bioinsecticide development due to their potency against insect pests and minimal activity, if any, in vertebrates (Maggio et al., 2010; Windley et al., 2012). Many of the peptides in Families 10-12, for example, display the type of phyletic selectivity that is desirable for an insecticide. In contrast, many of the peptides in Families 3-6 display a high degree of vertebrate lethality and therefore they would not be suitable as either pharmacological or insecticidal agents. Because venom-derived $\mathrm{Na}_{\mathrm{V}}$ channel modulators are genetically encoded, transgenes encoding the peptides can be incorporated into crop plants and entomopathogens in order to deliver them to targeted insect pests (Tedford et al., 2004; Windley et al., 2012). For example, the insecticidal potency of the Autographa californica nuclear polyhedrosis baculovirus was significantly improved by engineering it to express a transgene encoding $\mu$-AGTX-Aald ( $\mu$-Aga IV) from NaSpTx 
Family 10 (Prikhod'ko et al., 1996).

\section{NaSpTxs as therapeutic leads}

The extremely high stability, specificity, and potency of venom peptides, which in the case of spiders is the result of hundreds of millions of years of evolutionary fine tuning, have made them a valuable source of natural products for drug discovery (Lewis and Garcia, 2003; Escoubas and Bosmans, 2007; Fox and Serrano, 2007; Escoubas and King, 2009; Vetter et al., 2011). There are now six FDA-approved drugs derived from venom peptides or proteins, with a further ten in clinical trials and many more in various stages of preclinical development (King, 2011). Thus, the vast number of $\mathrm{Na}_{\mathrm{V}}$ channel modulators isolated from spider venoms begs the questions of whether any of these peptides might be useful therapeutically.

$\mathrm{Na}_{\mathrm{V}}$ channels are the target of several classes of therapeutics such as local anaesthetics (e.g. lidocaine and ropivacaine) and antiarrhythmics (e.g., mexiletine and flecainide), as well as anticonvulsants used to treat epilepsy or bipolar disorder (e.g., lamotrigine, carbamazepine, and phenytoin) (Clare et al., 2000; England and de Groot, 2009). Moreover, while most tricyclic antidepressants (e.g., amitriptyline and imipramine) are serotonin-norepinephrine reuptake inhibitors, they also inhibit $\mathrm{Na}_{\mathrm{V}}$ channels (Nicholson et al., 2002; Dick et al., 2007). However, currently, the major pharmaceutical interest in $\mathrm{Na}_{\mathrm{V}}$ channels stems from their involvement in pain. Indeed, many of the $\mathrm{Na}_{\mathrm{V}}$ channel drugs described above are now used for treating various types of pain, particularly post-operative and neuropathic pain.

Normal pain is a key adaptive response that serves to limit our exposure to potentially damaging or life-threatening events. In contrast, aberrant long-lasting pain transforms this adaptive response into a debilitating and often poorly managed disease. About $20 \%$ of adults suffer from chronic pain, with the incidence increasing to $50 \%$ for those older than 65 (Brennan et al., 2007). There are few drugs available for treating chronic pain and most have limited efficacy, dose-limiting side-effects, and in some cases the potential for addiction (Carinci and Mao, 2010). Hence, there is much interest in developing novel pain medications that have minimal or no side-effects and that do not have problems of tolerance and addiction.

Each of the nine $\mathrm{Na}_{\mathrm{V}}$ channel subtypes has a different anatomical distribution that determines their biological function. For example, $\mathrm{Na}_{\mathrm{V}} 1.5$ is restricted to the heart where it is critical for the rising phase of the cardiac action potential whereas $\mathrm{Na}_{\mathrm{V}} 1.4$ is restricted to muscle tissue 
and is critical for muscle contraction (England and de Groot, 2009; England and Rawson, 2010). The other seven subtypes are found in the central or peripheral nervous system. $\mathrm{Na}_{\mathrm{V}} 1.7$, $\mathrm{Na}_{\mathrm{V}} 1.8$ and $\mathrm{Na}_{\mathrm{V}} 1.9$ are selectively expressed in peripheral sensory neurons where they appear to play a key role in relaying pain signals to the spinal cord (Dib-Hajj et al., 2010). Of these subtypes, $\mathrm{Na}_{\mathrm{V}} 1.7$ has emerged as an exciting analgesic target based on several remarkable genetic studies. Gain-of-function mutations in the $S N C 9 A$ gene encoding the pore-forming $\alpha$ subunit of $\mathrm{Na}_{\mathrm{V}} 1.7$ have been shown to cause painful inherited neuropathies (primary erythromelalgia and paroxysmal extreme pain disorder) (Yang et al., 2004; Fertleman et al., 2006; Estacion et al., 2008). In contrast, loss-of-function mutations in $S C N 9 A$ result in a congenital indifference to all forms of pain (Cox et al., 2006; Nilsen et al., 2009). Remarkably, apart from their complete inability to sense pain, loss of smell (anosmia) is the only other sensory impairment in individuals with this channelopathy (Nilsen et al., 2009; Weiss et al., 2011; Rupasinghe et al., 2012).

It is probable that the known analgesic effects of a number of nonspecific $\mathrm{Na}_{\mathrm{V}}$ channel blockers such as local anaesthetics, anticonvulsants, and tricyclic antidepressants are at least in part mediated through their effects on $\mathrm{Na}_{\mathrm{v}} 1.7$ (Nicholson et al., 2002; Dick et al., 2007; Levinson et al., 2012). However, the non-specific block of $\mathrm{Na}_{\mathrm{V}}$ channels by these drugs results in a very narrow therapeutic window, with CNS-related side-effects such as dizziness, headaches, and ataxia, as well as potential cardiac side-effects (Cummins and Rush, 2007; Krafte and Bannon, 2008). Thus, there is much interest in the development of subtypeselective blockers of $\mathrm{Na}_{\mathrm{V}} 1.7$ (England and Rawson, 2010; Zuliani et al., 2010). In this regard, there are several reasons why NaSpTxs might be useful therapeutic leads for the development of Na $\mathrm{V}_{\mathrm{V}}$ 1.7-selective analgesics (Clare, 2010; England and Rawson, 2010; Saez et al., 2010). First, most NaSpTxs contain an ICK motif that provides them with tremendous chemical, thermal, and biological stability. Spider-venom ICK peptides are typically stable in human serum for several days and have half-lives in gastric fluid of $>12 \mathrm{~h}$ (Saez et al., 2010). Notably, an ICK scaffold forms the core of the analgesic drug Prialt ${ }^{\mathrm{TM}}$ (Miljanich, 2004). Second, because NaSpTxs are gating modifiers rather then pore blockers they are more likely to be subtype selective than small compounds that bind in the highly conserved pore of the channel. Nevertheless, our understanding of the molecular basis of the potency and selectivity of NaSpTxs, which is critical for their progression to the clinic, is still rudimentary. Indeed, it is remarkable that we only know the complete $\mathrm{Na}_{\mathrm{V}}$ selectivity profile for a handful of peptides 
in the 12 families of NaSpTxs.

Table 1 summarises some of the salient features of each NaSpTx family, including an indication of their subtype preferences. Notably, peptides that potently block $\mathrm{Na}_{\mathrm{V}} 1.5$ tend to be lethal in rodents, consistent with the critical role of this subtype in cardiac function. This highlights the need to pinpoint the residues on these peptides that mediate their selectivity and potency in order to be able to rationally engineer improved versions that preferentially bind $\mathrm{Na}_{\mathrm{V}}$ 1.7. This will be the major challenge in progressing these peptides to the clinic. On a positive note, however, peptides have already been isolated from Families 1-3 that potently block $\mathrm{Na}_{\mathrm{V}} 1.7\left(\mathrm{IC}_{50} \leq 51 \mathrm{nM}\right)$ and that have at least some selectivity over other $\mathrm{Na}_{\mathrm{V}}$ subtypes. Moreover, it is worth noting that parenterally administered NaSpTxs are unlikely to cross the blood-brain barrier and enter the CNS, and therefore off-target activity at centrally located $\mathrm{Na}_{\mathrm{V}}$ subtypes is unlikely to be a therapeutic problem.

In conclusion, it is clear that spiders have evolved a larger repertoire of $\mathrm{Na}_{\mathrm{V}}$ channel toxins than any other venomous animal. These $\mathrm{NaSpTxs}$ modulate $\mathrm{Na}_{\mathrm{V}}$ channels in a variety of different ways ranging from effects on the voltage-dependence of activation to the kinetics of channel inactivation. Many of these peptides have become useful pharmacological tools for studying the pharmacology and biophysics of $\mathrm{Na}_{\mathrm{V}}$ channels, while others are being developed as bioinsecticides due to their selective action on invertebrate $\mathrm{Na}_{\mathrm{V}}$ channels. In addition, many NaSpTxs are vertebrate-active and those with high potency and selectivity for certain $\mathrm{Na}_{\mathrm{V}}$ subtypes that are localised in peripheral pain pathways are being used as leads to develop novel classes of analgesics. Finally, it is worth noting that the 12 classes of NaSpTxs described here have been derived from only eight of the 110 extant families of spiders (Platnick, 1997). Thus, it is likely that additional classes of NaSpTxs will be discovered through better taxonomic sampling of the incredible diversity of spider venoms available. 


\section{References}

Adams, M.E., 2004. Agatoxins: ion channel specific toxins from the American funnel web spider, Agelenopsis aperta. Toxicon 43, 509-525.

Andrade, E., Villanova, F., Borra, P., Leite, K., Troncone, L., Cortez, I., Messina, L., Paranhos, M., Claro, J., and Srougi, M., 2008. Penile erection induced in vivo by a purified toxin from the Brazilian spider Phoneutria nigriventer. BJU Int. 102, 835-837.

Billen, B., Bosmans, F., and Tytgat, J., 2008. Animal peptides targeting voltage-activated sodium channels. Curr. Pharm. Des. 14, 2492-2502.

Bloomquist, J.E., Kinne, L.P., Deutsch, V., and Simpson, S.F., 1996. Mode of action of an insecticidal peptide toxin from the veom of a weaving spider (Diguetia canities). Toxicon 34, 1072-1075.

Bosmans, F., Rash, L., Zhu, S., Diochot, S., Lazdunski, M., Escoubas, P., and Tytgat, J., 2006. Four novel tarantula toxins as selective modulators of voltage-gated sodium channel subtypes. Mol. Pharmacol. 69, 419-429.

Bosmans, F., and Tytgat, J., 2007. Sea anemone venom as a source of insecticidal peptides acting on voltage-gated $\mathrm{Na}^{+}$channels. Toxicon 49, 550-560.

Bosmans, F., and Swartz, K.J., 2010. Targeting voltage sensors in sodium channels with spider toxins. Trends Pharmacol. Sci. 31, 175-182.

Brennan, F., Carr, D.B., and Cousins, M., 2007. Pain management: a fundamental human right. Anesth. Analg. 105, 205-221.

Carinci, A.J., and Mao, J., 2010. Pain and opioid addiction: what is the connection? Curr. Pain Headache Rep. 14, 17-21.

Catterall, W.A., Goldin, A.L., and Waxman, S.G., 2005. International Union of Pharmacology. XLVII. Nomenclature and structure-function relationships of voltagegated sodium channels. Pharmacol. Rev. 57, 397-409.

Catterall, W.A., Cestèle, S., Yarov-Yarovoy, V., Yu, F.H., Konoki, K., and Scheuer, T., 2007. Voltage-gated ion channels and gating modifier toxins. Toxicon 49, 124-141.

Chen, J., Deng, M., He, Q., Meng, E., Jiang, L., Liao, Z., Rong, M., and Liang, S., 2008. Molecular diversity and evolution of cystine knot toxins of the tarantula Chilobrachys jingzhao. Cell. Mol. Life Sci. 65, 2431-2444. 
Chen, J., Zhang, Y., Rong, M., Zhao, L., Jiang, L., Zhang, D., Wang, M., Mao, Y., and Liang, S.P., 2009. Expression and characterization of jingzhaotoxin-34, a novel neurotoxin from the venom of the tarantula Chilobrachys jingzhao. Peptides 30, 1042-1048.

Chen, J.Q., Zhang, Y.Q., Dai, J., Luo, Z.M., and Liang, S.P., 2005. Antinociceptive effects of intrathecally administered huwentoxin-I, a selective N-type calcium channel blocker, in the formalin test in conscious rats. Toxicon 45, 15-20.

Clare, J.J., Tate, S.N., Nobbs, M., and Romanos, M.A., 2000. Voltage-gated sodium channels as therapeutic targets. Drug Discov. Today 5, 506-520.

Clare, J.J., 2010. Targeting voltage-gated sodium channels for pain therapy. Expert Opin. Investig. Drugs 19, 45-62.

Coddington, J.A., and Levi, H.W., 1991. Systematics and evolution of spiders (Araneae). Annu. Rev. Ecol. Syst. 22, 565-592.

Cordeiro, M.N., Diniz, C.R., Valentim, A.C., von Eickstedt, V.R., Gilroy, J., and Richardson, M., 1992. The purification and amino acid sequences of four Tx2 neurotoxins from the venom of the Brazilian 'armed' spider Phoneutria nigriventer (Keys). FEBS Lett. 310, $153-156$.

Corzo, G., Escoubas, P., Stankiewicz, M., Pelhate, M., Kristensen, C.P., and Nakajima, T., 2000. Isolation, synthesis and pharmacological characterization of $\delta$-palutoxins IT, novel insecticidal toxins from the spider Paracoelotes luctuosus (Amaurobiidae). Eur. J. Biochem. 267, 5783-5795.

Corzo, G., Gilles, N., Satake, H., Villegas, E., Dai, L., Nakajima, T., and Haupt, J., 2003. Distinct primary structures of the major peptide toxins from the venom of the spider Macrothele gigas that bind to sites 3 and 4 in the sodium channel. FEBS Lett. 547, 43-50.

Corzo, G., Sabo, J.K., Bosmans, F., Billen, B., Villegas, E., Tytgat, J., and Norton, R.S., 2007. Solution structure and alanine scan of a spider toxin that affects the activation of mammalian voltage-gated sodium channels. J. Biol. Chem. 282, 4643-4652.

Cox, J.J., Reimann, F., Nicholas, A.K., Thornton, G., Roberts, E., Springell, K., Karbani, G., Jafri, H., Mannan, J., Raashid, Y., Al-Gazali, L., Hamamy, H., Valente, E.M., Gorman, S., Williams, R., McHale, D.P., Wood, J.N., Gribble, F.M., and Woods, C.G., 2006. An $S C N 9 A$ channelopathy causes congenital inability to experience pain. Nature $444,894-$ 898. 
Cummins, T.R., and Rush, A.M., 2007. Voltage-gated sodium channel blockers for the treatment of neuropathic pain. Expert Rev. Neurother. 7, 1597-1612.

Dib-Hajj, S.D., Cummins, T.R., Black, J.A., and Waxman, S.G., 2010. Sodium channels in normal and pathological pain. Annu. Rev. Neurosci. 33, 325-347.

Dick, I.E., Brochu, R.M., Purohit, Y., Kaczorowski, G.J., Martin, W.J., and Priest, B.T., 2007. Sodium channel blockade may contribute to the analgesic efficacy of antidepressants. J. Pain 8, 315-324.

Diniz, C.R., Cordeiro, M.D., Junor, L.R., Kelly, P., Fischer, S., Reimann, F., Oliveira, E.B., and Richardson, M., 1990. The purification and amino-acid-sequence of the lethal neurotoxin TX1 from the venom of the Brazilian armed spider Phoneutria nigriventer. FEBS Lett. 263, 251-253.

Diniz, M.R.V., Theakston, R.D.G., Crampton, J.M., Cordeiro, M.N., Pimenta, A.M.C., De Lima, M.E., and Diniz, C.R., 2006. Functional expression and purification of recombinant Tx1, a sodium channel blocker neurotoxin from the venom of the Brazilian "armed" spider, Phoneutria nigriventer. Protein Expr. Purif. 50, 18-24.

Diochot, S., Drici, M.D., Moinier, D., Fink, M., and Lazdunski, M., 1999. Effects of phrixotoxins on the Kv4 family of potassium channels and implications for the role of Ito1 in cardiac electrogenesis. Br. J. Pharmacol. 126, 251-263.

Edgerton, G.B., Blumenthal, K.M., and Hanck, D.A., 2010. Inhibition of the activation pathway of the T-type calcium channel Cav3.1 by ProTxII. Toxicon 56, 624-636.

Ekberg, J., Craik, D.J., and Adams, D.J., 2008. Conotoxin modulation of voltage-gated sodium channels. Int. J. Biochem. Cell. Biol. 40, 2363-2368.

England, S., and de Groot, M.J., 2009. Subtype-selective targeting of voltage-gated sodium channels. Br. J. Pharmacol. 158, 1413-1425.

England, S., and Rawson, D., 2010. Isoform-selective voltage-gated $\mathrm{Na}^{+}$channel modulators as next-generation analgesics. Future Med. Chem. 2, 775-790.

Escoubas, P., Sollod, B., and King, G.F., 2006. Venom landscapes: mining the complexity of spider venoms via a combined cDNA and mass spectrometric approach. Toxicon 47, 650663. 
Escoubas, P., and Bosmans, F., 2007. Spider peptide toxins as leads for drug development. Expert Opin. Drug Discov. 2, 823-835.

Escoubas, P., and King, G.F., 2009. Venomics as a drug discovery platform. Expert Rev. Proteomic. 6, 221-224.

Estacion, M., Dib-Hajj, S.D., Benke, P.J., Te Morsche, R.H., Eastman, E.M., Macala, L.J., Drenth, J.P., and Waxman, S.G., 2008. Na 1.7 gain-of-function mutations as a continuum: A1632E displays physiological changes associated with erythromelalgia and paroxysmal extreme pain disorder mutations and produces symptoms of both disorders. J. Neurosci. 28, 11079-11088.

Ferrat, G., Bosmans, F., Tytgat, J., Pimentel, C., Chagot, B., Gilles, N., Nakajima, T., Darbon, H., and Corzo, G., 2005. Solution structure of two insect-specific spider toxins and their pharmacological interaction with the insect voltage-gated $\mathrm{Na}^{+}$channel. Proteins $59,368-$ 379.

Fertleman, C.R., Baker, M.D., Parker, K.A., Moffatt, S., Elmslie, F.V., Abrahamsen, B., Ostman, J., Klugbauer, N., Wood, J.N., Gardiner, R.M., and Rees, M., 2006. SCN9A mutations in paroxysmal extreme pain disorder: allelic variants underlie distinct channel defects and phenotypes. Neuron 52, 767-774.

Fletcher, J.I., Chapman, B.E., Mackay, J.P., Howden, M.E., and King, G.F., 1997. The structure of versutoxin $(\delta$-atracotoxin-Hv1) provides insights into the binding of site 3 neurotoxins to the voltage-gated sodium channel. Structure 5, 1525-1535.

Fox, J.W., and Serrano, S.M.T., 2007. Approaching the golden age of natural product pharmaceuticals from venom libraries: an overview of toxins and toxin-derivatives currently involved in therapeutic or diagnostic applications. Curr. Pharm. Des. 13, 29272934.

Gordon, D., Karbat, I., Ilan, N., Cohen, L., Kahn, R., Gilles, N., Dong, K., Stuhmer, W., Tytgat, J., and Gurevitz, M., 2007. The differential preference of scorpion $\alpha$-toxins for insect or mammalian sodium channels: implications for improved insect control. Toxicon $49,452-472$.

Gouvea dos $\delta$ Santos, R., Diniz, C.R., Cordeiro, M.N., and De Lima, M.E., 1999. Binding sites and actions of Tx1, a neurotoxin from the venom of the spider Phoneutria nigriventer, in guinea pig ileum. Braz. J. Med. Biol.Res. 32, 1565-1569. 
Gouvea dos Santos, R., Van Renterghem, C., Martin-Moutot, N., Mansuelle, P., Cordeiro, M.N., Diniz, C.R., Mori, Y., De Lima, M.E., and Seagar, M., 2002. Phoneutria nigriventer $\omega$-phonetoxin IIA blocks the Cav2 family of calcium channels and interacts with $\omega$-conotoxin-binding sites. J. Biol. Chem. 277, 13856-13862.

Grolleau, F., Stankiewicz, M., Birinyi-Strachan, L., Wang, X.H., Nicholson, G.M., Pelhate, M., and Lapied, B., 2001. Electrophysiological analysis of the neurotoxic action of a funnel-web spider toxin, d-atracotoxin-HV1a, on insect voltage-gated $\mathrm{Na}^{+}$channels. $\mathrm{J}$. Exp. Biol. 204, 711-721.

Gunning, S.J., Chong, Y., Khalife, A.A., Hains, P.G., Broady, K.W., and Nicholson, G.M., 2003. Isolation of $\delta$-missulenatoxin-Mbla, the major vertebrate-active spider $\delta$-toxin from the venom of Missulena bradleyi (Actinopodidae). FEBS Lett 554, 211-218.

Heinemann, S.H., and Leipold, E., 2007. Conotoxins of the O-superfamily affecting voltagegated sodium channels. Cell. Mol. Life Sci. 64, 1329-1340.

Herrington, J., Zhou, Y.P., Bugianesi, R.M., Dulski, P.M., Feng, Y., Warren, V.A., Smith, M.M., Kohler, M.G., Garsky, V.M., Sanchez, M., Wagner, M., Raphaelli, K., Banerjee, P., Ahaghotu, C., Wunderler, D., Priest, B.T., Mehl, J.T., Garcia, M.L., McManus, O.B., Kaczorowski, G.J., and Slaughter, R.S., 2006. Blockers of the delayed-rectifier potassium current in pancreatic $\beta$-cells enhance glucose-dependent insulin secretion. Diabetes 55, $1034-1042$.

Herzig, V., Wood, D.L.A., Newell, F., Chaumeil, P.-A., Kaas, Q., Binford, G.J., Nicholson, G.M., Gorse, D., and King, G.F., 2011. ArachnoServer 2.0, an updated online resource for spider toxin sequences and structures. Nucleic Acids Res. 39, D653-D657.

Honma, T., and Shiomi, K., 2006. Peptide toxins in sea anemones: structural and functional aspects. Mar. Biotechnol. (NY) 8, 1-10.

King, G.F., Tedford, H.W., and Maggio, F., 2002. Structure and function of insecticidal neurotoxins from Australian funnel-web spiders. J. Toxicol.-Toxin Rev. 21, 359-389.

King, G.F., 2004. The wonderful world of spiders: preface to the special Toxicon issue on spider venoms. Toxicon 43, 471-476.

King, G.F., Escoubas, P., and Nicholson, G.M., 2008a. Peptide toxins that selectively target insect $\mathrm{Na}_{\mathrm{v}}$ and $\mathrm{Ca}_{\mathrm{v}}$ channels. Channels 2, 100-116. 
King, G.F., Gentz, M.C., Escoubas, P., and Nicholson, G.M., 2008b. A rational nomenclature for naming peptide toxins from spiders and other venomous animals. Toxicon 52, 264 276.

King, G.F., 2011. Venoms as a platform for human drugs: translating toxins into therapeutics. Expert Opin. Biol. Ther. 11, 1469-1484.

Krafte, D.S., and Bannon, A.W., 2008. Sodium channels and nociception: recent concepts and therapeutic opportunities. Curr. Opin. Pharmacol. 8, 50-56.

Krapcho, K.J., Kral Jr, R.M., Vanwagenen, B.C., Eppler, K.G., and Morgan, T.K., 1995. Characterization and cloning of insecticidal peptides from the primitive weaving spider Diguetia canities. Insect Biochem. Mol. Biol. 25, 991-1000.

Leipold, E., DeBie, H., Zorn, S., Borges, A., Olivera, B.M., Terlau, H., and Heinemann, S.H., 2007. $\mu \mathrm{O}$ conotoxins inhibit $\mathrm{Na}_{\mathrm{V}}$ channels by interfering with their voltage sensors in domain-2. Channels 1, 253-262.

Levinson, S.R., Luo, S., and Henry, M.A., 2012. The role of sodium channels in chronic pain. Muscle \& Nerve, in press (DOI:10.1002/mus.23314).

Lewis, R.J., and Garcia, M.L., 2003. Therapeutic potential of venom peptides. Nat. Rev. Drug Discov. 2, 790-802.

Li, D., Xiao, Y., Hu, W., Xie, J., Bosmans, F., Tytgat, J., and Liang, S., 2003. Function and solution structure of hainantoxin-I, a novel insect sodium channel inhibitor from the Chinese bird spider Selenocosmia hainana. FEBS Lett. 555, 616-622.

Li, D.L., Xiao, Y.C., Xu, X., Xiong, X.Y., Lu, S.Y., Liu, Z.H., Zhu, Q., Wang, M.C., Gu, X.C., and Liang, S.P., 2004. Structure-activity relationships of hainantoxin-IV and structure determination of active and inactive sodium channel blockers. J. Biol. Chem. $279,37734-37740$.

Li-Smerin, Y., and Swartz, K.J., 1998. Gating modifier toxins reveal a conserved structural motif in voltage-gated $\mathrm{Ca}^{2+}$ and $\mathrm{K}^{+}$channels. Proc. Natl. Acad. Sci. USA 95, 8585-8589.

Liang, S.P., Zhang, D.Y., Pan, X., Chen, Q., and Zhou, P.A., 1993. Properties and amino acid sequence of huwentoxin-I, a neurotoxin purified from the venom of the Chinese bird spider Selenocosmia huwena. Toxicon 31, 969-978. 
Liao, Z., Yuan, C., Deng, M., Li, J., Chen, J., Yang, Y., Hu, W., and Liang, S., 2006. Solution structure and functional characterization of Jingzhaotoxin-XI: A novel gating modifier of both potassium and sodium channels. Biochemistry 45, 15591-15600.

Little, M.J., Wilson, H., Zappia, C., Cestèle, S., Tyler, M.I., Martin-Eauclaire, M.F., Gordon, D., and Nicholson, G.M., 1998. $\delta$-atracotoxins from Australian funnel-web spiders compete with scorpion $\alpha$-toxin binding on both rat brain and insect sodium channels. FEBS Lett. 439, 246-252.

Liu, Z., Dai, J., Chen, Z., Hu, W., Xiao, Y., and Liang, S., 2003. Isolation and characterization of hainantoxin-IV, a novel antagonist of tetrodotoxin-sensitive sodium channels from the Chinese bird spider Selenocosmia hainana. Cell. Mol. Life Sci. 60, 972-978.

Maggio, F., Sollod, B.L., Tedford, H.W., Herzig, V., and King, G.F., 2010. Spider toxins and their potential for insect control. In: Gilbert, L.I.a.G., S.S. (Eds), Insect Pharmacology: Channels, Receptors, Toxins and Enzymes, Academic Press, Oxford, pp. 101-123.

Martin-Moutot, N., Mansuelle, P., Alcaraz, G., Dos Santos, R.G., Cordeiro, M.N., De Lima, M.E., Seagar, M., and Van Renterghem, C., 2006. Phoneutria nigriventer toxin 1: A novel, state-dependent inhibitor of neuronal sodium channels that interacts with $\mu$ conotoxin binding sites. Mol. Pharmacol. 69, 1931-1937.

Matavel, A., Cruz, J.S., Penaforte, C.L., Araujo, D.A., Kalapothakis, E., Prado, V.F., Diniz, C.R., Cordeiro, M.N., and Beirao, P.S., 2002. Electrophysiological characterization and molecular identification of the Phoneutria nigriventer peptide toxin PnTx2-6. FEBS Lett $523,219-223$.

Middleton, R.E., Warren, V.A., Kraus, R.L., Hwang, J.C., Liu, C.J., Dai, G., Brochu, R.M., Kohler, M.G., Gao, Y.D., Garsky, V.M., Bogusky, M.J., Mehl, J.T., Cohen, C.J., and Smith, M.M., 2002. Two tarantula peptides inhibit activation of multiple sodium channels. Biochemistry 41, 14734-14747.

Miljanich, G.P., 2004. Ziconotide: neuronal calcium channel blocker for treating severe chronic pain. Curr. Med. Chem. 11, 3029-3040.

Moran, Y., Gordon, D., and Gurevitz, M., 2009. Sea anemone toxins affecting voltage-gated sodium channels - molecular and evolutionary features. Toxicon 54, 1089-1101. 
Mylecharane, E.J., Spence, I., Sheumack, D.D., Claassens, R., and Howden, M.E., 1989. Actions of robustoxin, a neurotoxic polypeptide from the venom of the male funnel-web spider (Atrax robustus), in anaesthetized monkeys. Toxicon 27, 481-492.

Nicholson, G.M., Little, M.J., Tyler, M., and Narahashi, T., 1996. Selective alteration of sodium channel gating by Australian funnel-web spider toxins. Toxicon 34, 1443-1453.

Nicholson, G.M., Walsh, R., Little, M.J., and Tyler, M.I., 1998. Characterisation of the effects of robustoxin, the lethal neurotoxin from the Sydney funnel-web spider Atrax robustus, on sodium channel activation and inactivation. Pflügers Archiv. (Eur. J. Physiol.) 436, 117-126.

Nicholson, G.M., Blanche, T., Mansfield, K., and Tran, Y., 2002. Differential blockade of neuronal voltage-gated $\mathrm{Na}^{+}$and $\mathrm{K}^{+}$channels by antidepressant drugs. Eur. J. Pharmacol. $452,35-48$.

Nicholson, G.M., Little, M.J., and Birinyi-Strachan, L.C., 2004. Structure and function of $\delta$ atracotoxins: lethal neurotoxins targeting the voltage-gated sodium channel. Toxicon 43 , $587-599$.

Nicholson, G.M., and Little, M.J., 2005. Spider neurotoxins targeting voltage-gated sodium channels. Toxin Rev. 24, 315-345.

Nilsen, K.B., Nicholas, A.K., Woods, C.G., Mellgren, S.I., Nebuchennykh, M., and Aasly, J., 2009. Two novel SCN9A mutations causing insensitivity to pain. Pain 143, 155-158.

Norton, R.S., 1991. Structure and structure-function relationships of sea anemone proteins that interact with the sodium channel. Toxicon 29, 1051-1084.

Nunes, K.P., Costa-Goncalves, A., Lanza, L.F., Cortes, S.F., Cordeiro, M.N., Richardson, M., Pimenta, A.M., Webb, R.C., Leite, R., and De Lima, M.E., 2008. Tx2-6 toxin of the Phoneutria nigriventer spider potentiates rat erectile function. Toxicon 51, 1197-1206.

Oswald, R.E., Suchyna, T.M., McFeeters, R., Gottlieb, P., and Sachs, F., 2002. Solution structure of peptide toxins that block mechanosensitive ion channels. J. Biol. Chem. 277, $34443-34450$.

Pallaghy, P.K., Nielsen, K.J., Craik, D.J., and Norton, R.S., 1994. A common structural motif incorporating a cystine knot and a triple-stranded $\beta$-sheet in toxic and inhibitory polypeptides. Protein Sci. 3, 1833-1839. 
Payandeh, J., Scheuer, T., Zheng, N., and Catterall, W.A., 2011. The crystal structure of a voltage-gated sodium channel. Nature 475, 353-358.

Platnick, N.I., 1997. Advances in spider taxonomy, 1992-1995: with redescriptions 19401980 (updated online version available at http://research.amnh.org/entomology/spiders/catalog/). New York Entomological Society $\&$ The American Museum of Natural History, New York.

Priest, B.T., Blumenthal, K.M., Smith, J.J., Warren, V.A., and Smith, M.M., 2007. ProTx-I and ProTx-II: Gating modifiers of voltage-gated sodium channels. Toxicon 49, 194-201.

Prikhod'ko, G.G., Robson, M., Warmke, J.W., Cohen, C.J., Smith, M.M., Wang, P., Warren, V., Kaczorowski, G., Van der Ploeg, L.H.T., and Miller, L.K., 1996. Properties of three baculovirus-expressing genes that encode insect-selective toxins: $\mu$-Aga-IV, As II, and Sh I. Biol. Control 7, 236-244.

Redaelli, E., Cassulini, R.R., Silva, D.F., Clement, H., Schiavon, E., Zamudio, F.Z., Odell, G., Arcangeli, A., Clare, J.J., Alagón, A., de la Vega, R.C.R., Possani, L.D., and Wanke, E., 2010. Target promiscuity and heterogeneous effects of tarantula venom peptides affecting $\mathrm{Na}^{+}$and $\mathrm{K}^{+}$ion channels. J. Biol. Chem. 285, 4130-4142.

Richardson, M., Pimenta, A.M.C., Bemquerer, M.P., Santoro, M.M., Beirao, P.S.L., Lima, M.E., Figueiredo, S.G., Bloch, C., Vasconcelos, E.A.R., Campos, F.A.P., Gomes, P.C., and Cordeiro, M.N., 2006. Comparison of the partial proteomes of the venoms of Brazilian spiders of the genus Phoneutria. Comp. Biochem. Physiol. C Toxicol. Pharmacol. 142, 173-187.

Rodriguez de la Vega, R.C., and Possani, L.D., 2005. Overview of scorpion toxins specific for $\mathrm{Na}^{+}$channels and related peptides: biodiversity, structure-function relationships and evolution. Toxicon 46, 831-844.

Rong, M., Chen, J., Tao, H., Wu, Y., Jiang, P., Lu, M., Su, H., Chi, Y., Cai, T., Zhao, L., Zeng, X., Xiao, Y., and Liang, S., 2011. Molecular basis of the tarantula toxin jingzhaotoxin-III $(\beta$-TRTX-Cj1 $\alpha)$ interacting with voltage sensors in sodium channel subtype Nav1.5. FASEB J. 25, 3177-3185.

Rupasinghe, D., O., K., Scmid, A.B., Adams, D.J., King, G.F., and Ruitenberg, M.J., 2012. Localization of $\mathrm{Na}_{\mathrm{V}} 1.7$ in the normal and injured rodent olfactory system indicates a critical role in olfaction, pheromone sensing and immune function. Channels, in press. 
Saez, N.J., Senff, S., Jensen, J.E., Er, S.Y., Herzig, V., Rash, L.D., and King, G.F., 2010. Spider-venom peptides as therapeutics Toxins 2, 2851-2871.

Satake, H., Villegas, E., Oshiro, N., Terada, K., Shinada, T., and Corzo, G., 2004. Rapid and efficient identification of cysteine-rich peptides by random screening of a venom gland cDNA library from the hexathelid spider Macrothele gigas. Toxicon 44, 149-156.

Schmalhofer, W.A., Calhoun, J., Burrows, R., Bailey, T., Kohler, M.G., Weinglass, A.B., Kaczorowski, G.J., Garcia, M.L., Koltzenburg, M., and Priest, B.T., 2008. ProTx-II, a selective inhibitor of $\mathrm{Na}_{\mathrm{V}} 1.7$ sodium channels, blocks action potential propagation in nociceptors. Mol. Pharmacol. 74, 1476-1484.

Skinner, W.S., Adams, M.E., Quistad, G.B., Kataoka, H., Cesarin, B.J., Enderlin, F.E., and Schooley, D.A., 1989. Purification and characterization of 2 classes of neurotoxins from the funnel web spider, Agelenopsis Aperta. J. Biol. Chem. 264, 2150-2155.

Soderlund, D.M., and Knipple, D.C., 1995. Actions of insecticides on sodium-channelsmultiple-target sites and site-specific resistance In: Clark, J.M. (Eds), Molecular Action of Insecticides on Ion Channels, Vol. 591, pp. 97-108.

Sokolov, S., Kraus, R.L., Scheuer, T., and Catterall, W.A., 2007. Inhibiting of sodium channel gating by trapping the domain II voltage sensor with protoxin II. Mol. Pharmacol. $73,1020-1028$.

Stapleton, A., Blankenship, D.T., Ackermann, B.L., Chen, T.M., Gorder, G.W., Manley, G.D., Palfreyman, M.G., Coutant, J.E., and Cardin, A.D., 1990. Curtatoxins. Neurotoxic insecticidal polypeptides isolated from the funnel-web spider Hololena curta. J. Biol. Chem. 265, 2054-2059.

Szeto, T.H., Birinyi-Strachan, L.C., Smith, R., Connor, M., Christie, M.J., King, G.F., and Nicholson, G.M., 2000. Isolation and pharmacological characterisation of $\delta$-atracotoxinHv1b, a vertebrate-selective sodium channel toxin. FEBS Lett. 470, 293-299.

Tedford, H.W., Sollod, B.L., Maggio, F., and King, G.F., 2004. Australian funnel-web spiders: master insecticide chemists. Toxicon 43, 601-618.

Vetter, I., Davis, J.L., Rash, L.D., Anangi, R., Mobli, M., Alewood, P.F., Lewis, R.J., and King, G.F., 2011. Venomics: a new paradigm for natural products-based drug discovery. Amino Acids 40, 15-28. 
Wang, M., Rong, M., Xiao, Y., and Liang, S., 2011. Huwentoxin-I, a multifunctional toxin that preferentially targets cockroach voltage-gated sodium channels. Peptides In press

Weinberger, H., Moran, Y., Gordon, D., Turkov, M., Kahn, R., and Gurevitz, M., 2010. Positions under positive selection-key for selectivity and potency of scorpion $\alpha$-toxins. Mol. Biol. Evol. 27, 1025-1034.

Weiss, J., Pyrski, M., Jacobi, E., Bufe, B., Willnecker, V., Schick, B., Zizzari, P., Gossage, S.J., Greer, C.A., Leinders-Zufall, T., Woods, C.G., Wood, J.N., and Zufall, F., 2011. Loss-of-function mutations in sodium channel $\mathrm{Na}_{\mathrm{V}} 1.7$ cause anosmia. Nature 472, 186 190.

Wilson, M.J., Yoshikami, D., Azam, L., Gajewiak, J., Olivera, B.M., Bulaj, G., and Zhang, M.M., 2011. $\mu$-Conotoxins that differentially block sodium channels $\mathrm{Na}_{\mathrm{V}} 1.1$ through 1.8 identify those responsible for action potentials in sciatic nerve. Proc. Natl. Acad. Sci. USA 108, 10302-10307.

Windley, M.J., Herzig, V., Dziemborowicz, S.A., Hardy, M.C., King, G.F., and Nicholson, G.M., 2012. Spider-venom peptides as bioinsecticides. Toxins 4, in press.

Wood, D.L., Miljenovic, T., Cai, S., Raven, R.J., Kaas, Q., Escoubas, P., Herzig, V., Wilson, D., and King, G.F., 2009. ArachnoServer: a database of protein toxins from spiders. BMC Genomics 10, 375.

Xiao, Y., and Liang, S., 2003a. Inhibition of neuronal tetrodotoxin-sensitive $\mathrm{Na}^{+}$channels by two spider toxins: hainantoxin-III and hainantoxin-IV. Eur. J. Pharmacol. 477, 1-7.

Xiao, Y., Tang, J., Hu, W., Xie, J., Maertens, C., Tytgat, J., and Liang, S., 2005. Jingzhaotoxin-I, a novel spider neurotoxin preferentially inhibiting cardiac sodium channel inactivation. J. Biol. Chem. 280, 12069-12076.

Xiao, Y., Bingham, J.P., Zhu, W., Moczydlowski, E., Liang, S., and Cummins, T.R., 2008. Tarantula huwentoxin-IV inhibits neuronal sodium channels by binding to receptor site 4 and trapping the domain II voltage sensor in the closed configuration. J. Biol. Chem. 283, $27300-27313$.

Xiao, Y.C., and Liang, S.P., 2003b. Purification and characterization of Hainantoxin-V, a tetrodotoxin-sensitive sodium channel inhibitor from the venom of the spider Selenocosmia hainana. Toxicon 41, 643-650. 
Yamaji, N., Little, M.J., Nishio, H., Billen, B., Villegas, E., Nishiuchi, Y., Tytgat, J., Nicholson, G.M., and Corzo, G., 2009. Synthesis, solution structure, and phylum selectivity of a spider $\delta$-toxin that slows inactivation of specific voltage-gated sodium channel subtypes. J. Biol. Chem. 284, 24568-24582.

Yang, Y., Wang, Y., Li, S., Xu, Z., Li, H., Ma, L., Fan, J., Bu, D., Liu, B., Fan, Z., Wu, G., Jin, J., Ding, B., Zhu, X., and Shen, Y., 2004. Mutations in $S C N 9 A$, encoding a sodium channel $\alpha$ subunit, in patients with primary erythermalgia. J. Med. Genet. 41, 171-174.

Zeng, X., Deng, M., Lin, Y., Yuan, C., Pi, J., and Liang, S., 2007. Isolation and characterization of Jingzhaotoxin- $\mathrm{V}$, a novel neurotoxin from the venom of the spider Chilobrachys jingzhao. Toxicon 49, 388-399.

Zeng, X.Z., Xiao, Q.B., and Liang, S.P., 2003. Purification and characterization of raventoxin-I and raventoxin-III, two neurotoxic peptides from the venom of the spider Macrothele raveni. Toxicon 41, 651-656.

Zlotkin, E., 1999. The insect voltage-gated sodium channel as target of insecticides. Annu. Rev. Entomol. 44, 49-55.

Zuliani, V., Rivara, M., Fantini, M., and Costantino, G., 2010. Sodium channel blockers for neuropathic pain. Expert Opin. Ther. Pat. 20, 755-779. 


\section{Figure Legends}

Fig. 1: Ion channel modulators from spider venoms. Molecular targets of the 186 ion channel toxins listed in ArachnoServer (www.arachnoserver.org; accessed February 12, 2012) (Herzig et al., 2011). The majority of toxins target voltage-gated ion channels $\left(\mathrm{Ca}_{\mathrm{V}}\right.$, $\mathrm{Na}_{\mathrm{V}}$, and $\left.\mathrm{K}_{\mathrm{V}}\right)$, followed by calcium-activated potassium $\left(\mathrm{K}_{\mathrm{Ca}}\right)$ channels, mechanosensitive ion channels (MSC), transient receptor potential (TRP) channels, and acid-sensing ion channels (ASICs). Note that some toxins target more than one type of channel, and therefore the cumulative number of toxins in the histogram is $>186$.

Fig. 2: Molecular architecture and pharmacology of $\mathrm{Na}_{\mathbf{v}}$ channels. The pore-forming $\alpha$ subunit of $\mathrm{Na}_{\mathrm{V}}$ channels is comprised of four homologous domains denoted I-IV connected by intracellular linkers. Each of these domains contains six transmembrane (TM) helical segments (labelled 1-6) joined by intra- or extracellular loops. TM segments 5 and 6 from each domain, along with the intervening membrane re-entrant loops (highlighted with a green box), come together to form the channel pore and the ion-selectivity filter at the extracellular end of the pore. TM segments 1-4 of each domain form the voltage-sensing units, as indicated for domain I; the highly positively charged TM segment 4 is primarily responsible for sensing changes in membrane polarization. Sodium channel inactivation is mediated by a short stretch of hydrophobic residues (the "inactivation gate") in the intracellular linker connecting domains III and IV. Coloured regions represent neurotoxin receptor sites. The grey circles represent the outer (EEDD) and inner (DEKA) rings of amino acid residues that form the ion selectivity filter and constitute the proposed neurotoxin receptor site 1 for the water-soluble guanidinium toxins TTX and saxitoxin. Some $\mu$-conotoxin binding sites overlap with those of TTX and are omitted for clarity. Nevertheless, we refer to sites $1 \mathrm{a}$ and $1 \mathrm{~b}$ to distinguish between the different molecular determinants for $\mu$-conotoxin and TTX/saxitoxin binding. In the case of receptor sites 3 and 4, only epitopes where mutagenesis of key residues leads to more than a five-fold decrease in toxin binding affinity are highlighted. Note that TM segment 6 in domain I includes binding epitopes for both site 2 and site 5 toxins. The known binding sites for 8 of the 12 families of spider-venom $\mathrm{Na}_{\mathrm{V}}$ toxins (NaSpTxs) are indicated. "F" denotes toxin family (e.g., F2 indicates NaSpTx Family 2). While the $\delta$-amaurobitoxins in Family 10 have been shown to bind to neurotoxin receptor site 4, peptides in this family have variable pharmacology and some may bind at other sites. Adapted from (Catterall et al., 2007; King et al., 2008a). 
Fig. 3: NaSpTx families $1-4,7$ and 10. The consensus sequence is shown above each alignment, with the disulfide-bond connectivity indicated in blue. Asterisks denote C-terminal amidation. Toxin names are based on the rational nomenclature devised for spider-venom peptides (King et al., 2008b), as used in ArachnoServer and UniProt (King et al., 2008b). The structure of a representative member from each NaSpTx family is shown adjacent to each alignment: Family 1, $\mu$-TRTX-Hh2a (PDB ID: 1MB6); Family 2, к-TRTX-Gr1a (PDB ID:

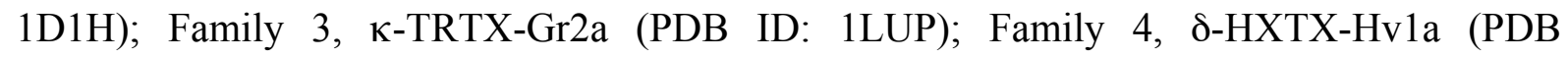
ID:1VTX); Family 7, к-TRTX-Gr3a (PDB ID: 1S6X); Family 10, $\delta$-AMATX-P11b (PDB ID: 1V91). $\beta$-Strands are depicted in cyan, helices are red, and disulfide bridges are yellow. All spider photos were taken by Bastian Rast.

Fig. 4: NaSpTx families 5, 6, 8, 9, 11 and 12. The consensus sequence is shown above each alignment, with the disulfide-bond connectivity indicated in blue. Dotted lines represent predicted disulfide-bond connectivities that have not been experimentally validated. Asterisks denote C-terminal amidation. Toxin names are based on the rational nomenclature devised for spider-venom peptides (King et al., 2008b), as used in ArachnoServer and UniProt. The structure of a representative member of Family 5 is shown adjacent to each alignment ( $\beta$-HXTX-Mg1a; PDB ID: 2GX1). Disulfide bridges are coloured yellow. No structures are available for any member of the other NaSpTx families depicted in this figure. Spider photos are by Bastian Rast (M. gigas and P. reidyi) and Aloys Staudt (H. melloteei). 